\title{
KONDISI KUALITAS PERAIRAN DAN PRODUKTIVITAS PERIKANAN BUDIDAYA DI WADUK CIRATA, JAWA BARAT: KEMUNGKINAN DAMPAK PEMANASAN GLOBAL
}

\author{
Adang Saputra"), I Nyoman Radiarta*), dan Erlania**) \\ ") Balai Penelitian dan Pengembangan Budidaya Air Tawar \\ Jl. Sempur No. 1, Bogor 16151 \\ E-mail: adang_pusrisdkp@yahoo.com \\ **) Pusat Penelitian dan Pengembangan Perikanan Budidaya \\ Jl. Ragunan 20, Pasar Minggu, Jakarta Selatan 12540
}

(Naskah diterima: 14 November 2012; Disetujui publikasi: 25 Maret 2013)

\begin{abstract}
ABSTRAK
Salah satu penyebab terjadinya perubahan ekosistem perairan adalah pemanasan global. Waduk Cirata berpotensi menerima dampak dari perubahan iklim sehingga dapat mempengaruhi produktivitas ikan yang dibudidayakan. Pemanasan global juga dapat berpengaruh terhadap fluktuasi muka air kawasan waduk/danau disebabkan perubahan curah hujan dan presipitasi, yang tentunya sangat berpengaruh bagi keberlangsungan kegiatan perikanan di Waduk Cirata. Tujuan dari penelitian ini mengkaji kondisi kualitas perairan dan tingkat produktivitas perikanan budidaya di Waduk Cirata, Jawa Barat, serta melihat kemungkinan adanya dampak dari pemanasan global. Hasil analisis terhadap lingkungan perairan dan klimatologi menunjukkan bahwa secara umum suhu udara dari tahun 2008-2011 terus meningkat, hal ini dapat dijadikan sebagai salah satu indikator terjadinya pemanasan global. Sedangkan produksi ikan dari kegiatan budidaya di keramba jaring apung terus menurun dari 141.861,03 ton tahun 2007 menjadi 133.492,45 ton tahun 2009. Hal ini memberikan indikasi kemungkinan adanya pengaruh dari pemanasan global terhadap penurunan produksi ikan di Waduk Cirata.
\end{abstract}

KATA KUNCI: pemanasan global, produksi akuakultur, keramba jaring apung, Waduk Cirata

ABSTRACT: Water quality condition and productivity of freshwater aquaculture in Cirata Reservoir, West Java: possible impact of climate change. By: Adang Saputra, I Nyoman Radiarta, and Erlania

One causes of aquatic ecosystem change is global warming. Cirata Reservoir could be potentially affected by global warming toward the productivity of farmed fish. Global warming could also affect the reservoir's water level fluctuation due to changes in rainfall and precipitation. This could influence the sustainability of aquaculture development in Cirata Reservoir. The aim of this study was to observe water quality condition and productivity of freshwater aquaculture in Cirata Reservoir, West Java, and observed the possible impact of climate change. The results of environmental parameters and climatology data analyses showed that the overall air temperature trend from 2008-2011 continues to increase, and this could be used as an indicator of global warming. Moreover, fish production from floating net cages aquaculture has declined from 141,861.03 tonnes in 2007 to 133,492.45 tonnes in 2009. These results 
gave an indication on the possibel impact of global warming to the decline in fish production in the Reservoir Cirata.

\section{KEYWORDS: global warming, aquaculture production, cage culture, Cirata Reservoir}

\section{PENDAHULUAN}

Permasalahan utama di semua ekosistem perairan di Indonesia adalah eutrofikasi (pengkayaan nutrien), sedimentasi, dan pencemaran. Apabila sumberdaya perairan dan ekosistemnya rusak, maka energi yang merupakan sumber fungsi utama akan menjadi masalah yang serius. Perairan merupakan indikator pertama yang menerima dampak dari kerusakan ekosistem tersebut. Salah satu penyebab terjadinya kerusakan ekosistem perairan adalah perubahan iklim. Dampak adanya fenomena penyimpangan iklim yang terjadi di wilayah Indonesia di antaranya: banjir, longsor, kekeringan, gagal panen, gagal tanam, kebakaran hutan, gelombang pasang, dan angin puting beliung (Rusbiantoro, 2008).

Pemanasan global adalah meningkatnya suhu rata-rata di atmosfir, laut, dan daratan. Bagi Indonesia, meskipun konstribusinya terhadap percepatan pemanasan global tidak sebesar negara-negara maju, tetapi tetap menjadi perhatian dalam pembahasan iklim global. Hal utama yang diperhatikan dari Indonesia terhadap percepatan pemanasan global di antaranya percepatan kerusakan hutan, padahal hutan tropis merupakan paru-paru bumi yang menyerap paling banyak karbon dari udara (Rusbiantoro, 2008).

Pemanasan global diproyeksikan akan berpengaruh terhadap kondisi ekosistem, kondisi sosial dan ekonomi, meningkatnya tekanan terhadap sumber mata pencaharian yang berimplikasi pada penyediaan pangan, termasuk pengaruhnya bagi kegiatan akuakultur. Di bidang akuakultur, perubahan yang terjadi baik berupa tingkat produktivitas, distribusi, komposisi spesies, dan lingkungan sehingga dapat menyebabkan perubahan dalam operasional akuakultur. Menurut Cochrane et al. (2009), ada empat kategori pengaruh signifikan dari pemanasan global terhadap ketahanan pangan yaitu: (1) ketersediaan (availability) pangan akan bervariasi karena perubahan lingkungan, ketersediaan stok ikan, dan distribusinya; (2) stabilitas (stability) penyediaan pangan akan terpengaruh karena perubahan musim, meningkatnya perubahan produktivitas ekosistem dan variabilitas suplai pangan, dan risiko; (3) akses (access) kepada sumber pangan akan dipengaruhi karena perubahan mata pencaharian dan kesempatan berusaha; dan (4) pemanfaatan (utilization) dari produksi perikanan juga akan terpengaruh, sebagai contoh masyarakat perlu menyesuaikan diri dengan jenis ikan yang sebelumnya belum pernah dikonsumsi.

Penelitian dampak pemanasan global terhadap perikanan budidaya masih sangat terbatas. Beberapa pustaka yang ada umumnya masih bersifat review tentang kemungkinan dampak yang ditimbulkan baik dampak secara langsung (direct impact) maupun tidak langsung (indirect impact) (Bardach, 1989; Meisner \& Shuter, 1992; Harley et al., 2006; Cochrane et al., 2009; Radiarta et al., 2011). Secara global, Handisyde et al. (2006) telah melakukan analisis kemungkinan dampak dari perubahan iklim terhadap perikanan budidaya. Secara umum dampak langsung yang mungkin ditimbulkan dengan perubahan suhu (udara/ air) adalah kelayakan dari suatu jenis ikan untuk dibudidayakan di lokasi tertentu, sedangkan dampak tidak langsung berupa pengaruh terhadap kandungan oksigen, terjadinya penyakit, dan terjadinya kelimpahan alga beracun. Pemanasan global juga dapat berpengaruh terhadap fluktuasi muka air kawasan waduk/danau yang disebabkan perubahan curah hujan dan presipitasi, yang tentunya sangat berpengaruh bagi keberlangsungan kegiatan perikanan di waduk/ danau. Penelitian yang sifatnya lebih spesifik terhadap perikanan budidaya (misalnya produktivitas perikanan air tawar) sangat diperlukan guna dapat memberikan dukungan data dan informasi yang relevan mengenai dampak pemanasan global terhadap tingkat produktivitas perikanan budidaya.

Produktivitas adalah produksi dibagi dengan selang waktu tertentu atau dibagi luas lahan yang digunakan (Sudradjat, 2006). Tingkat produktivitas kawasan Waduk Cirata dapat dipengaruhi oleh berbagai aspek, baik dari dalam waduk maupun dari luar waduk. 
Aspek dari dalam waduk yang dapat mempengaruhi di antaranya kondisi kualitas perairan, jumlah keramba jaring apung (KJA) yang dioperasionalkan, dan pola budidaya yang diaplikasikan (jenis pakan, frekuensi pemberian pakan, dan lain-lain), serta aktivitas lainnya selain budidaya perikanan. Sedangkan kondisi iklim (klimatologi dan meteorologi), pola pemanfaatan lahan, dan kondisi sosial kemasyarakatan merupakan beberapa aspek dari luar waduk yang dapat mempengaruhi tingkat produktivitas waduk tersebut. Beberapa kajian telah dilakukan untuk melihat dampak yang mempengaruhi tingkat produktivitas Waduk Cirata baik dari dalam maupun dari luar waduk (Prihadi, 2005; Widiyati et al., 2011 ; Radiarta et al., 2011; Widiyati \& Begen, 2012). Umumnya kajian yang dilakukan hanya berkonsentrasi pada dampaknya terhadap Waduk Cirata, namun belum melihat hubungannya dengan data iklim atau anomali iklim yang terjadi belakangan ini. Tujuan dari penelitian ini adalah untuk mengkaji kondisi kualitas perairan dan tingkat produktivitas perikanan budidaya di Waduk Cirata serta melihat kemungkinan dampak dari pemanasan global.

\section{BAHAN DAN METODE}

Penelitian ini dilakukan di Waduk Cirata, Provinsi Jawa Barat (Gambar 1). Data yang dikumpulkan dalam penelitian ini meliputi data primer dan data sekunder. Data primer diperoleh dengan metode survai lapangan. Pengambilan data dilakukan sebanyak empat kali yakni pada musim peralihan bulan Mei 2011 (pengamatan 1), dan musim panas pada bulan Juni 2011 (pengamatan 2), Juli 2011 (pengamatan 3), dan Agustus 2011 (pengamatan 4). Sebanyak 15 titik pengamatan kualitas perairan disebar secara acak di kawasan waduk, sehingga dapat mewakili karakteristik waduk yang disurvai (Gambar 1). Pengambilan data kualitas air dilakukan secara stratifikasi kedalaman yaitu: $0 \mathrm{~m}, 5 \mathrm{~m}, 10 \mathrm{~m}, 25 \mathrm{~m}, 40 \mathrm{~m}$, $60 \mathrm{~m}$, dan dasar perairan. Pengukuran secara stratifikasi ini disesuaikan dengan kedalaman perairan di masing-masing lokasi pengamatan.

Pengumpulan data kualitas air mengacu pada Meisner \& Shuter (1992), di mana parameter lingkungan perairan yang utama terkena dampak dari pemanasan global adalah peningkatan suhu perairan, penurunan kandungan oksigen (DO), dan peningkatan pencemaran bahan beracun. Untuk perairan tergenang seperti waduk, eutrofikasi akan semakin buruk dengan sering terjadinya stratifikasi suhu sehingga akan berpengaruh terhadap rantai makanan dan kualitas/ketersediaan habitat yang sesuai.

Data sekunder yang dikumpulkan meliputi produktivitas perikanan (jumlah KJA dan produksi), volume air waduk, dan data klimatologi

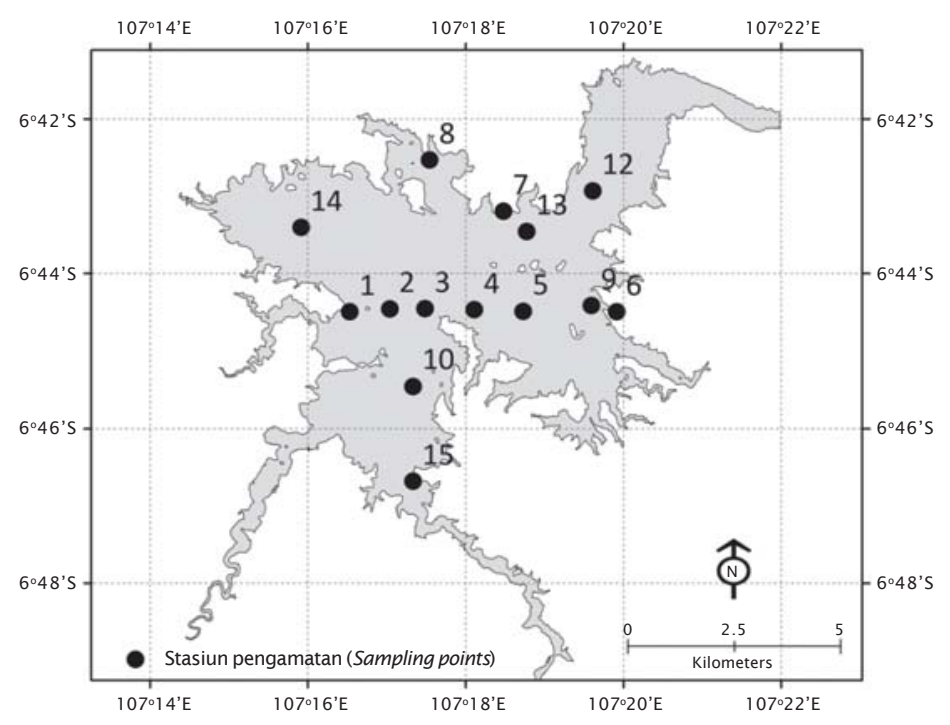

Gambar 1. Lokasi titik pengambilan data kualitas perairan di Waduk Cirata, Jawa Barat

Figure 1. Sampling station for water quality measurement in Cirata Reservoir, West Java 
(suhu udara, curah hujan, dan kecepatan angin). Data tersebut dikumpulkan dari berbagai instansi yaitu Dinas Kelautan dan Perikanan (DKP) Provinsi Jawa Barat, Badan Pengelola Waduk Cirata (BPWC), Unit Pembangkit JawaBali (UPJB), dan Balai Pelestarian Perikanan Perairan Umum (BP3U) Cianjur.

Analisis data dilakukan secara spasial dan deskriptif. Analisis spasial kualitas air secara stratifikasi (vertikal) menggunakan Ocean Data View (ODV) (Schlitzer, 2011). Analisis stratifikasi ini dilakukan secara melintang (stasiun 15, 10, $3,4,13$, dan 12) dan membujur (stasiun 1, 2, 3, $4,5,6$, dan 9).

\section{HASIL DAN BAHASAN}

\section{Kondisi Umum Waduk Cirata}

Waduk Cirata merupakan salah satu waduk yang dibangun di daerah aliran sungai (DAS) Citarum pada tahun 1988 yang terletak antara Waduk Saguling dan Jatiluhur. Posisi Waduk Cirata berada pada ketinggian $221 \mathrm{~m}$ dpl dan mempunyai luas 6.200 ha, kedalaman maksimum mencapai $106 \mathrm{~m}$, dan volume air maksimum 2.165 juta $\mathrm{m}^{3}$ (Husen, 2004). Waduk Cirata dibangun selain untuk kepentingan pembangkit tenaga listrik, juga telah dijadikan sebagai pusat kegiatan perekonomian bagi masyarakat di sekitar waduk, di antaranya pariwisata dan perikanan.

Kondisi Waduk Cirata sampai saat ini telah mengalami penurunan mutu lingkungan yang sangat serius (Prihadi, 2005, Widiyati \& Begen, 2012). Luasan waduk yang makin lama semakin sempit dengan kedalaman air yang makin berkurang. Menurut Radiarta et al. (2005), pada saat musim penghujan (April 2002) luas waduk mencapai 5.794 ha, luas ini mengalami penurunan saat musim kemarau (September 2002) yaitu 4.664 ha. Kedalaman perairan Waduk Cirata juga mengalami degradasi di mana kedalaman maksimum hanya $89 \mathrm{~m}$ dibandingkan dengan saat pertama kali waduk ini dioperasikan kedalamannya mencapai $106 \mathrm{~m}$.

Saat ini Waduk Cirata merupakan sentra kegiatan budidaya ikan air tawar di Jawa Barat dengan sistem keramba jaring apung (KJA). Jumlah KJA Pada tahun 2009 mencapai 51.418 unit dan yang masih operasional sekitar $60 \%$ atau sebanyak 30.850 unit dengan jumlah rumah tangga petani (RTP) adalah 2.838 , namun produksinya dari tahun ke tahun cenderung terus menurun (BPWC, 2009).

\section{Kondisi Perairan Waduk Cirata}

Kondisi volume air di Waduk Cirata juga terindikasi mengalami penurunan. Tinggi muka air terus menurun sejak tahun 1992, hanya pada tahun 2010 volume air mengalami sedikit peningkatan disebabkan musim hujan yang cukup panjang pada tahun tersebut (Gambar 2). Sedangkan pada tahun 2011 tinggi permukaan air terlihat terus mengalami penurunan yang cukup signifikan. Keadaan ini masih jauh di bawah permukaan air pada tahun 2010,

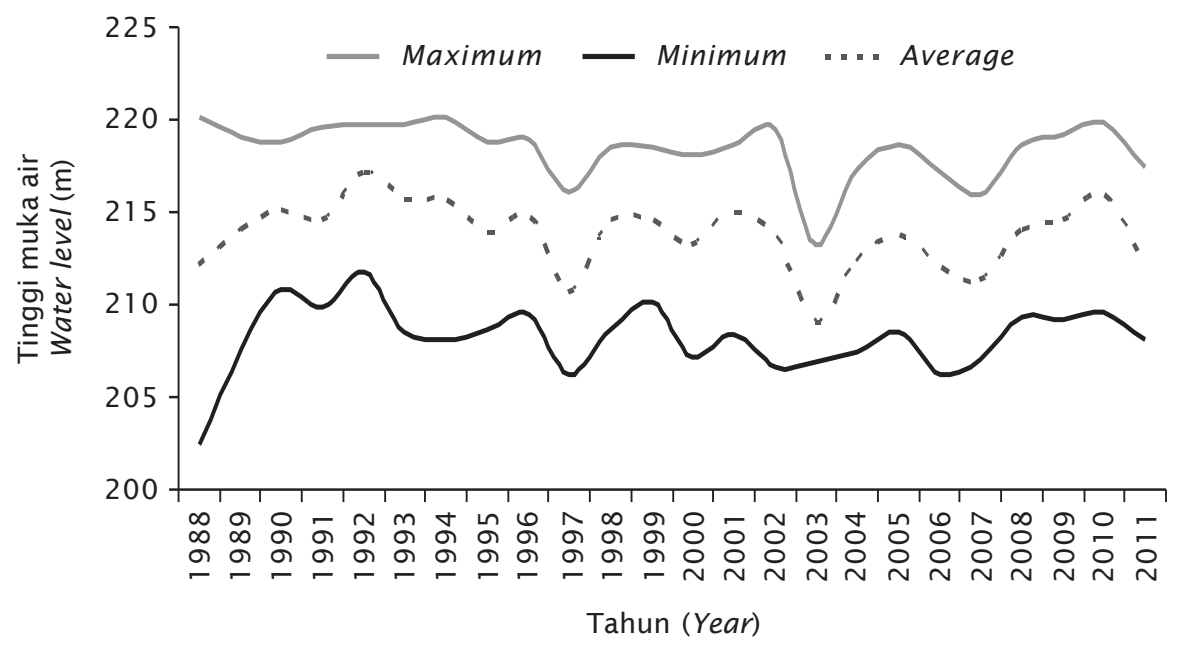

Gambar 2. Tinggi muka air Waduk Cirata dari tahun 1988-2011 (Sumber: BPWC (2011)

Figure 2. Water level of Cirata Reservoir from 1988-2011 (Source: BPWC (2011) 
sehingga data ini menggambarkan bahwa volume air Waduk Cirata terus mengalami penurunan akibat dari volume air yang masuk terus berkurang.

Pada Gambar 3 terlihat dari volume air yang masuk ke Waduk Cirata di tahun 2011 berbanding lurus dengan tinggi permukaan airnya. Pada Bulan April 2011 volume air yang masuk cukup tinggi karena pada bulan tersebut merupakan puncak musim hujan. Pada bulan berikutnya volume air terus menurun disebabkan sudah memasuki musim kemarau. Volume air yang masuk ke Waduk Cirata pada tahun 2011 masih jauh di bawah volume air yang masuk pada tahun 2010 (Gambar 3).

\section{Profil Vertikal Kualitas Perairan}

Profil vertikal dari beberapa parameter penting yang besar kemungkinan terkena dampak pemanasan global disajikan baik secara melintang (stasiun 15, 10, 3, 4, 13, dan 12) dan membujur (stasiun 1, 2, 3, 4, 5, 6, dan 9) di perairan Waduk Cirata. Pembahasan dari masing-masing parameter tersebut disajikan berikut ini:

\section{Suhu Air}

Suhu air merupakan salah satu faktor yang sangat penting dalam mengatur metabolisme serta penyebaran organisme dan mempengaruhi sifat fisik kimiawi perairan. Kenaikan suhu dapat menurunkan kandungan oksigen serta menaikan daya toksik yang ada dalam suatu perairan. Suhu juga berpengaruh langsung pada organisme perairan tertentu di dalam proses fotosintesis tumbuhan akuatik dan siklus reproduksi (Sverdrup et al., 1961). Menurut Gunarso (1985), ikan sangat peka terhadap perubahan suhu walaupun hanya $0,03^{\circ} \mathrm{C}$.

Hasil analisis terhadap suhu air secara membujur dan melintang dengan stratifikasi kedalaman yang berbeda ditampilkan pada Gambar 4 dan 5. Dari 4 kali pengamatan dengan waktu yang berbeda menunjukkan distribusi suhu yang tidak sama. Secara umum suhu air di Waduk Cirata terus menurun seiring dengan musim hujan. Terlihat pada pengukuran bulan Mei suhu air sampai kedalaman $10 \mathrm{~m}$ masih ideal untuk budidaya ikan berkisar antara $28^{\circ} \mathrm{C}-30^{\circ} \mathrm{C}$, baik dilihat secara membujur dan melintang. Namun kondisi ini tidak bertahan sepanjang tahun, terlihat dari hasil analisis pada bulan Agustus suhu permukaan air di bawah $29^{\circ} \mathrm{C}$. Kondisi ini sangat rawan untuk budidaya ikan, karena dapat mengakibatkan kematian pada ikan yang dipelihara. Menurut Tarsim (2000), suhu air sangat berkaitan dengan konsentrasi oksigen dalam air dan laju konsumsi oksigen hewan air. Saputra et al. (2007) mengemukakan bahwa suhu air merupakan salah satu parameter kualitas air yang memegang peranan penting di dalam kehidupan dan pertumbuhan biota perairan.

Suhu perairan mempunyai kaitan yang cukup erat dengan besarnya intensitas cahaya yang masuk ke dalam suatu perairan. Dalam

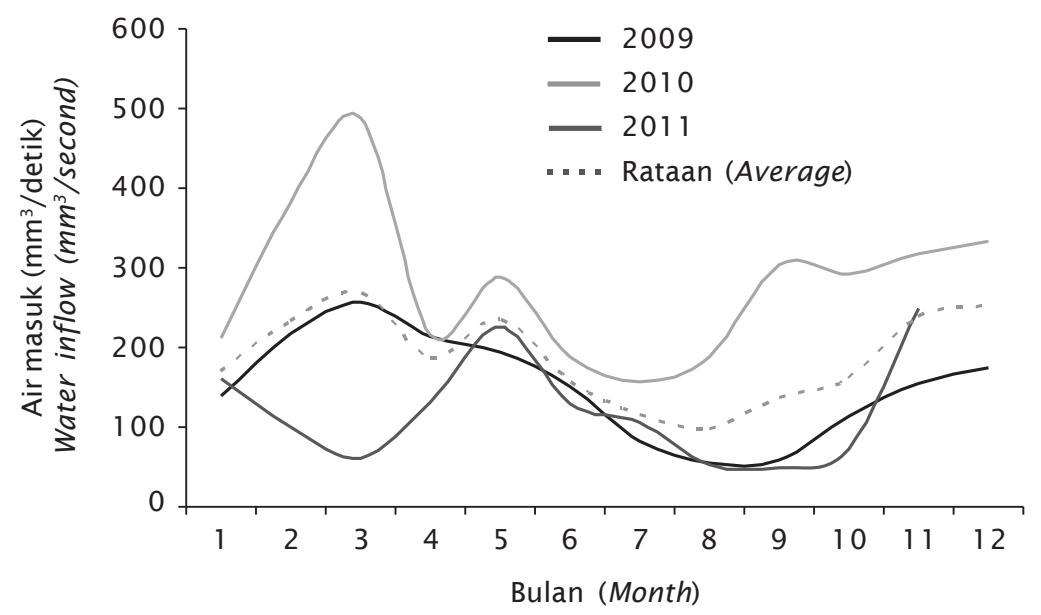

Gambar 3. Volume air masuk ke Waduk Cirata tahun 2010 dan 2011 (Sumber: BPWC (2011)

Figure 3. Water inflow to Cirata Reservoir from 2010-2011 (Source: BPWC (2011) 
Suhu (Temperature) (1)

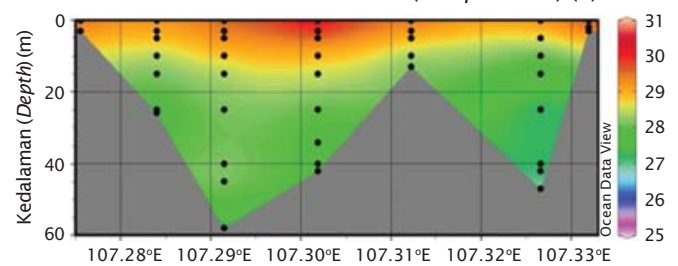

Suhu (Temperature) (3)

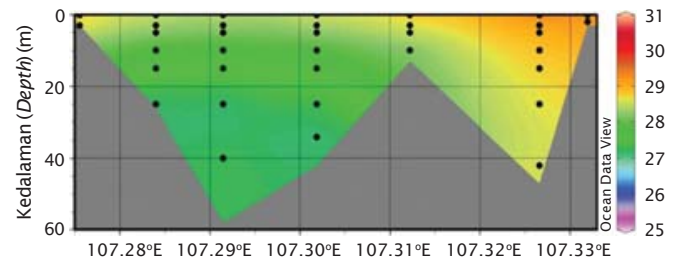

Suhu (Temperature) (2)

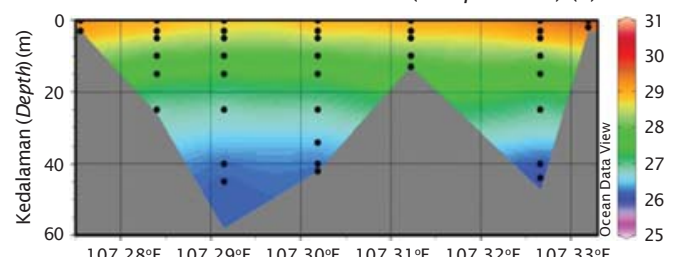

Suhu (Temperature) (4)

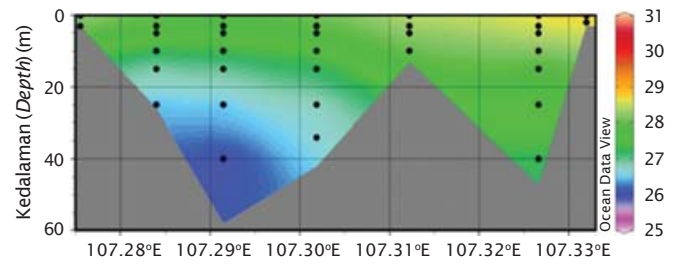

Gambar 4. Profil suhu perairan secara membujur (stasiun 1, 2, 3, 4, 5, 6, dan 9) untuk waktu pengamatan yang berbeda: (1) 2 Mei, (2) 10 Juni, (3) 29 Juli, dan (4) 20 Agustus 2011

Figure 4. Water temperature profile along the longitude (station 1, 2, 3, 4, 5, 6, and 9) for different time observation: (1) 2 May, (2) 10 June, (3) 29 July, and (4) 20 August 2011

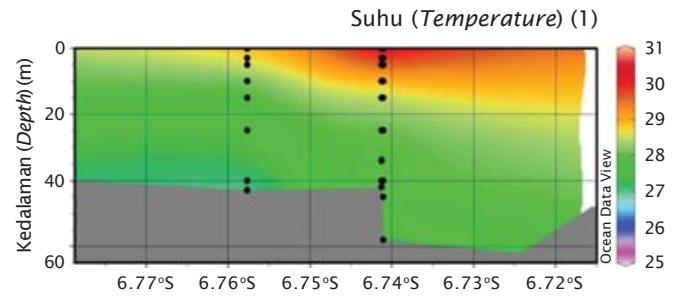

Suhu (Temperature) (3)

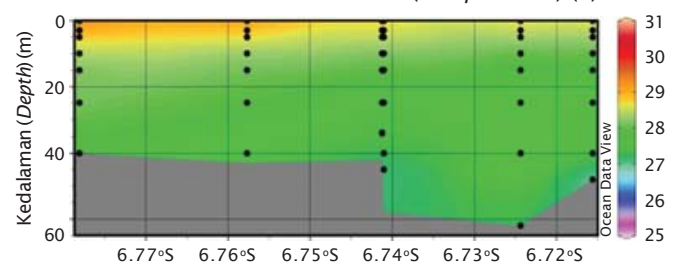

Suhu (Temperature) (2)

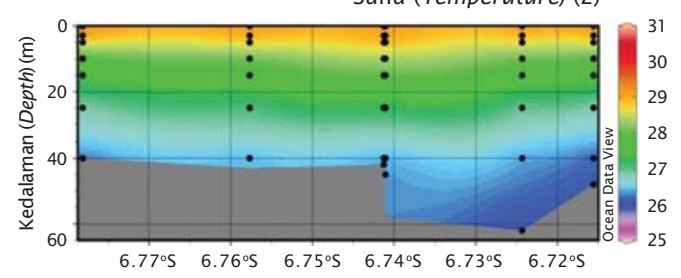

Suhu (Temperature) (4)

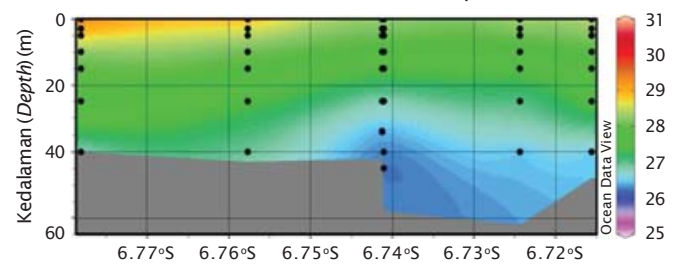

Gambar 5. Profil suhu perairan secara melintang (stasiun 15, 10, 3, 4, 13, dan 12) untuk waktu pengamatan yang berbeda: (1) 2 Mei, (2) 10 Juni, (3) 29 Juli, dan (4) 20 Agustus 2011

Figure 5. Water temperature profile along the latitude (station 15, 10, 3, 4, 13, and 12) for different time observation: (1) 2 May, (2) 10 June, (3) 29 July, and (4) 20 August 2011

hal ini intensitas cahaya yang masuk ke dalam suatu perairan akan menentukan derajat panas, yakni semakin banyak sinar matahari yang masuk ke dalam suatu perairan, semakin tinggi suhu airnya. Menurut Nontji (1993), suhu yang terdeteksi di permukaan air dipengaruhi oleh keadaan meteorologi seperti curah hujan, penguapan, kelembaban udara, kecepatan angin, dan intensitas radiasi sinar matahari.

\section{Oksigen Terlarut (DO)}

Kelarutan oksigen merupakan salah satu faktor kualitas air yang paling kritis dalam budidaya ikan di kolam, sehingga perubahan oksigen sedikit saja langsung dapat dirasakan oleh ikan. Kelarutan oksigen dipengaruhi oleh suhu, tekanan parsial gas, dan salinitas (Boyd \& Licthkoppler, 1982). Selanjutnya dinyatakan 
bahwa sumber oksigen di kolam berasal dari fotosintesis fitoplankton dan difusi dari udara, sedangkan penyebab utama berkurangnya kelarutan oksigen adalah karena respirasi plankton, respirasi ikan, respirasi organisme dasar, dan difusi ke udara.

Hasil analisis vertikal parameter DO pada perairan Waduk Cirata secara membujur dan melintang ditampilkan pada Gambar 6 dan 7.
Profil tersebut menunjukkan DO perairan di Waduk Cirata sudah berada pada ambang batas yang kurang optimum untuk budidaya ikan dan kondisinya terus menurun dari bulan Mei sampai Agustus, hal ini berbanding lurus dengan suhu perairan. Khususnya pada bulan Agustus, DO di permukaan air sudah di bawah $5 \mathrm{mg} / \mathrm{L}$. Hasil ini sangat mendukung informasi kondisi di lapangan karena pada bulan Agustus

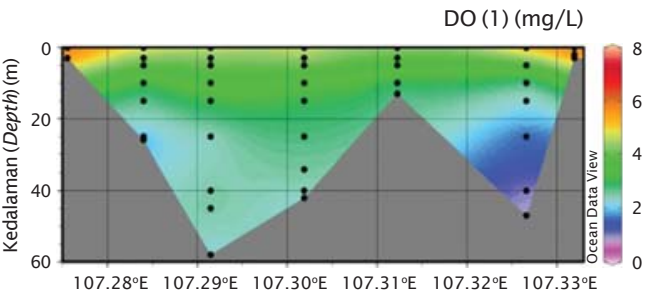

$\mathrm{DO}(3)(\mathrm{mg} / \mathrm{L})$

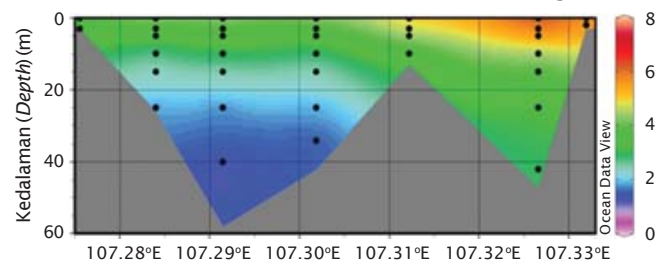

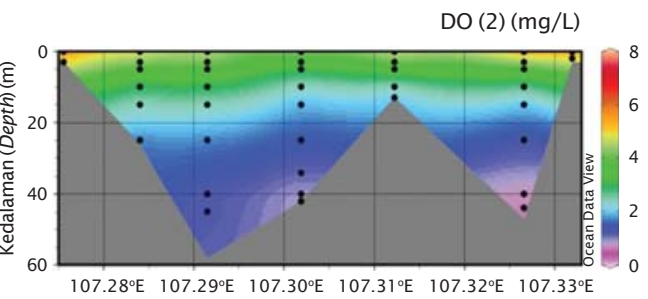

$\mathrm{DO}(4)(\mathrm{mg} / \mathrm{L})$

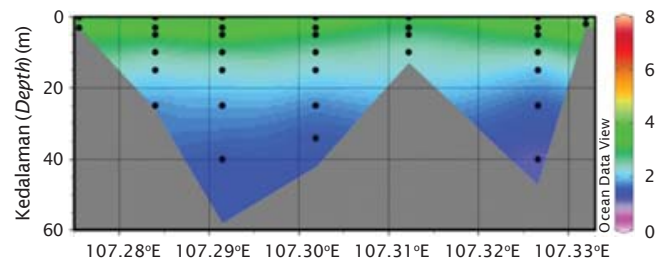

Gambar 6. Profil oksigen terlarut secara membujur (stasiun 1, 2, 3, 4, 5, 6, dan 9) untuk waktu pengamatan yang berbeda: (1) 2 Mei, (2) 10 Juni, (3) 29 Juli, dan (4) 20 Agustus 2011

Figure 6. Dissolve oxygen profile along the longitude (station 1, 2, 3, 4, 5, 6, and 9) for different time observation: (1) 2 May, (2) 10 June, (3) 29 July, and (4) 20 August 2011

$\mathrm{DO}(1)(\mathrm{mg} / \mathrm{L})$

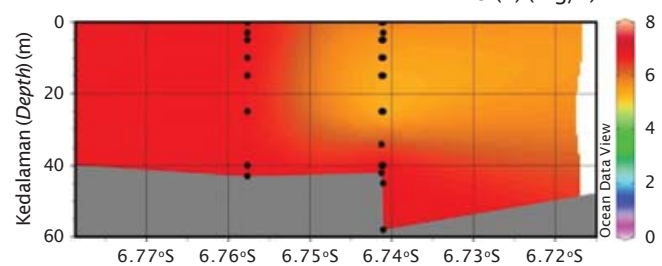

DO (3) (mg/L)

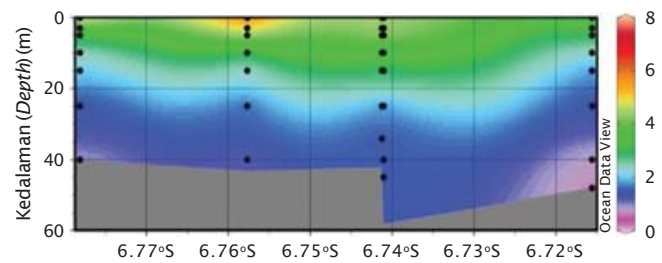

$\mathrm{DO}(2)(\mathrm{mg} / \mathrm{L})$

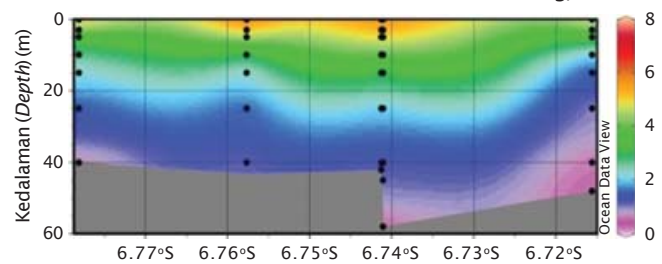

DO (4) $(\mathrm{mg} / \mathrm{L})$

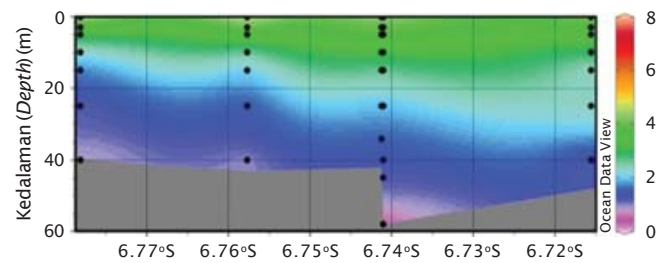

Gambar 7. Profil oksigen terlarut secara melintang (stasiun 15, 10, 3, 4, 13, dan 12) untuk waktu pengamatan yang berbeda: (1) 2 Mei, (2) 10 Juni, (3) 29 Juli, dan (4) 20 Agustus 2011

Figure 7. Dissolve oxygen profile along the latitude (station 15, 10, 3, 4, 13, and 12) for different time observation: (1) 2 May, (2) 10 June, (3) 29 July, and (4) 20 August 2011 
tahun 2011 terjadi kematian walaupun tidak massal. Pendapat ini dikuatkan oleh Cholik et al. (1986) dan Sunarti (1992), bila konsentrasi oksigen terlarut tetap sebesar 3 atau $4 \mathrm{mg} / \mathrm{L}$ untuk jangka waktu lama maka ikan akan menghentikan aktivitas dan pertumbuhannya akan berhenti. Pada bulan ini pembudidaya ikan harus hati-hati karena dikhawatirkan adanya penurunan DO yang menggambarkan juga suhu perairan semakin menurun, diduga terjadinya umbalan tidak bisa dihindari lagi. Apabila sudah terjadi umbalan maka kematian ikan secara massal akan terjadi, sehingga pada bulan ini sebaiknya dihindari untuk stok ikan yang ukurannya besar, karena ikan yang besar akan lebih cepat mati kekurangan oksigen dibandingkan dengan ikan yang masih ukuran benih.

\section{Keasaman $(\mathrm{pH})$}

Tingkat keasaman $(\mathrm{pH})$ adalah suatu ukuran untuk menyatakan besarnya konsentrasi ion hidrogen $\left(\mathrm{H}^{+}\right)$di dalam air (Tebbut, 1992 dalam Effendi, 2003). Nilai pH menunjukkan derajat keasaman atau kebasaan suatu perairan. Mackereth et al. (1989) berpendapat bahwa, $\mathrm{pH}$ juga berkaitan erat dengan karbondioksida dan alkalinitas. Pada $\mathrm{pH}<5$, alkalinitas dapat mencapai nol. Semakin tinggi nilai $\mathrm{pH}$, semakin tinggi pula nilai alkalinitas dan semakin rendah kadar karbondioksida bebas. Larutan yang bersifat asam $(\mathrm{pH})$ rendah bersifat korosif. Dalam keadaan tidak ada oksigen akan dihasilkan hidrogen sulfida $\left(\mathrm{H}_{2} \mathrm{~S}\right)$, amonia $\left(\mathrm{NH}_{3}\right)$, dan metana $\left(\mathrm{CH}_{4}\right)$. Hampir semua senyawa yang dihasilkan tersebut bersifat asam yang pada akhirnya akan menurunkan $\mathrm{pH}$. Zat tersebut akan digunakan untuk proses fotosintesis, sehingga kandungan karbondioksida akan menurun, dan ion bikarbonat $\left(\mathrm{HCO}_{3}^{-}\right)$akan berubah menjadi $\mathrm{CO}_{2}$ dan ion $\mathrm{OH}$. Adanya dominasi ion hidroksil ini mengakibatkan $\mathrm{pH}$ air meningkat (Prihadi, 2005).

Hasil analisis terhadap pH air Waduk Cirata menunjukkan bahwa perairannya masih optimum untuk budidaya ikan, karena nilainya masih berada pada kisaran 6-8 (Gambar 8 dan 9). Boyd \& Licthkoppler (1982) menyatakan kisaran $\mathrm{pH}$ pada budidaya ikan adalah sebagai berikut: $\mathrm{pH} 4$ dan 11 adalah titik mati asam dan basa, $\mathrm{pH}$ antara 4 dan 6, dan antara 9 dan 10, ikan dapat hidup tapi pertumbuhannya lambat, sedangkan pH 6,5 dan 9 merupakan kisaran optimum bagi kehidupan ikan. Supaya ikan dapat tumbuh maksimal, $\mathrm{pH}$ harus tetap ideal dengan fluktuasi yang kecil (Stickney, 2000).

\section{$\mathrm{H}_{2} \mathrm{~S}$}

Konsentrasi $\mathrm{H}_{2} \mathrm{~S}$ di Waduk Cirata masih tergolong rendah, terlihat dari hasil analisis vertikal secara membujur (Gambar 10) dan melintang (Gambar 11). Namun demikian kondisinya sudah dalam ambang tidak optimum karena sudah mendekati kisaran 0,002 mg/L
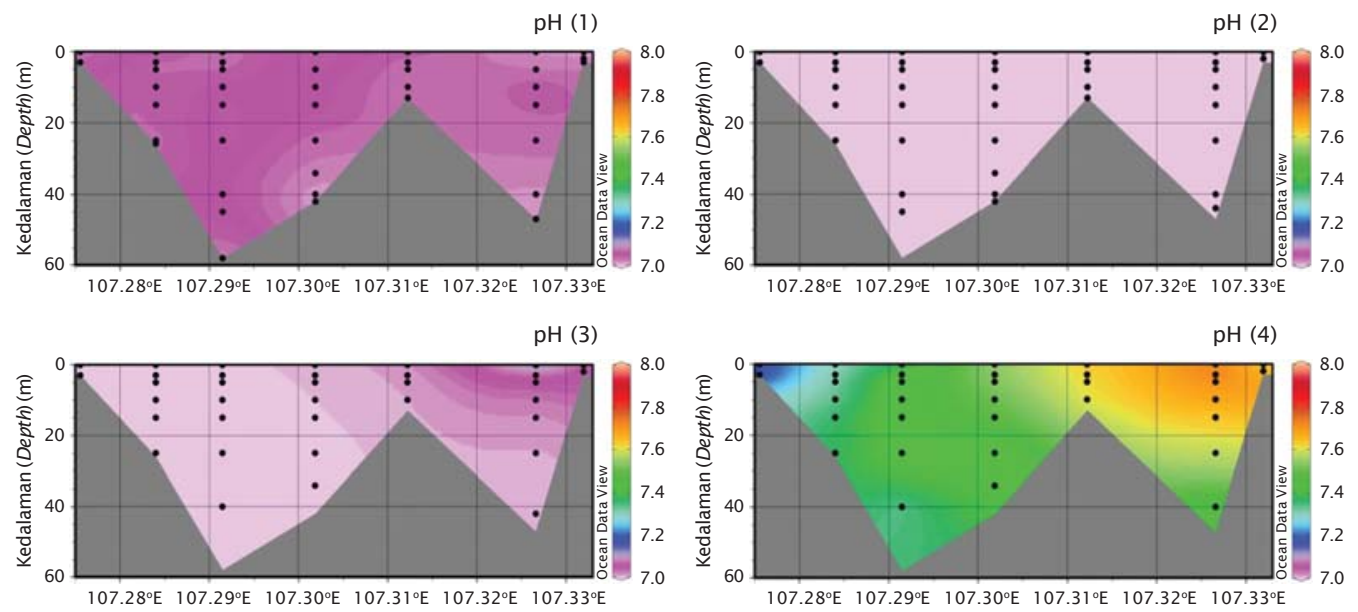

Gambar 8. Profil pH perairan secara membujur (stasiun 1, 2, 3, 4, 5, 6, dan 9) untuk waktu pengamatan yang berbeda: (1) 2 Mei, (2) 10 Juni, (3) 29 Juli, dan (4) 20 Agustus 2011

Figure 8. $\mathrm{pH}$ profile along the longitude (station 1, 2, 3, 4, 5, 6, and 9) for different time observation: (1) 2 May, (2) 10 June, (3) 29 July, and (4) 20 August 2011 
$\mathrm{pH}(1)$

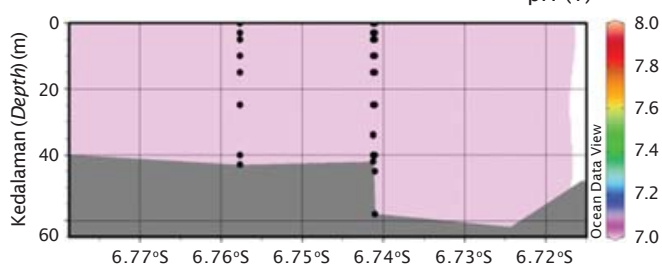

$\mathrm{pH}(3)$

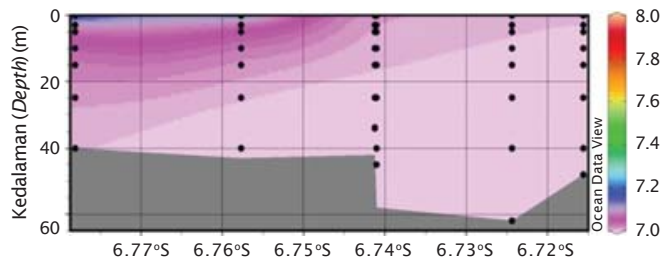

$\mathrm{pH}(2)$

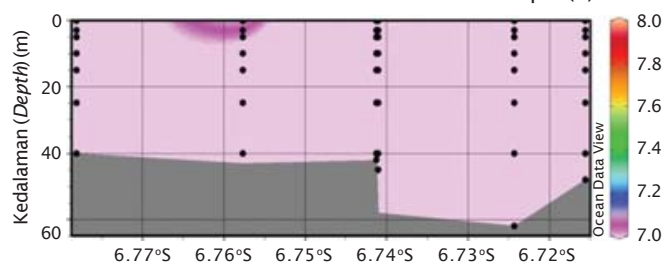

$\mathrm{pH}(4)$

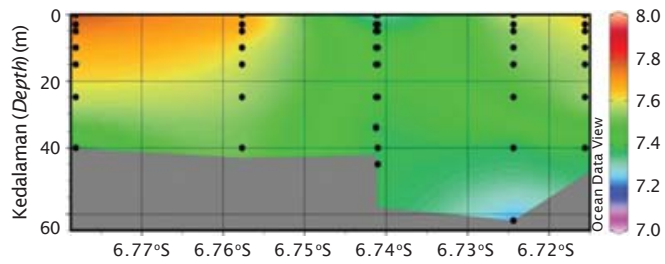

Gambar 9. Profil pH perairan secara melintang (stasiun 15, 10, 3, 4, 13, dan 12) untuk waktu pengamatan yang berbeda: (1) 2 Mei, (2) 10 Juni, (3) 29 Juli, dan (4) 20 Agustus 2011

Figure 9. $\mathrm{pH}$ profile along the latitude (station 15, 10, 3, 4, 13, and 12) for different time observation: (1) 2 May, (2) 10 June, (3) 29 July, and (4) 20 August 2011
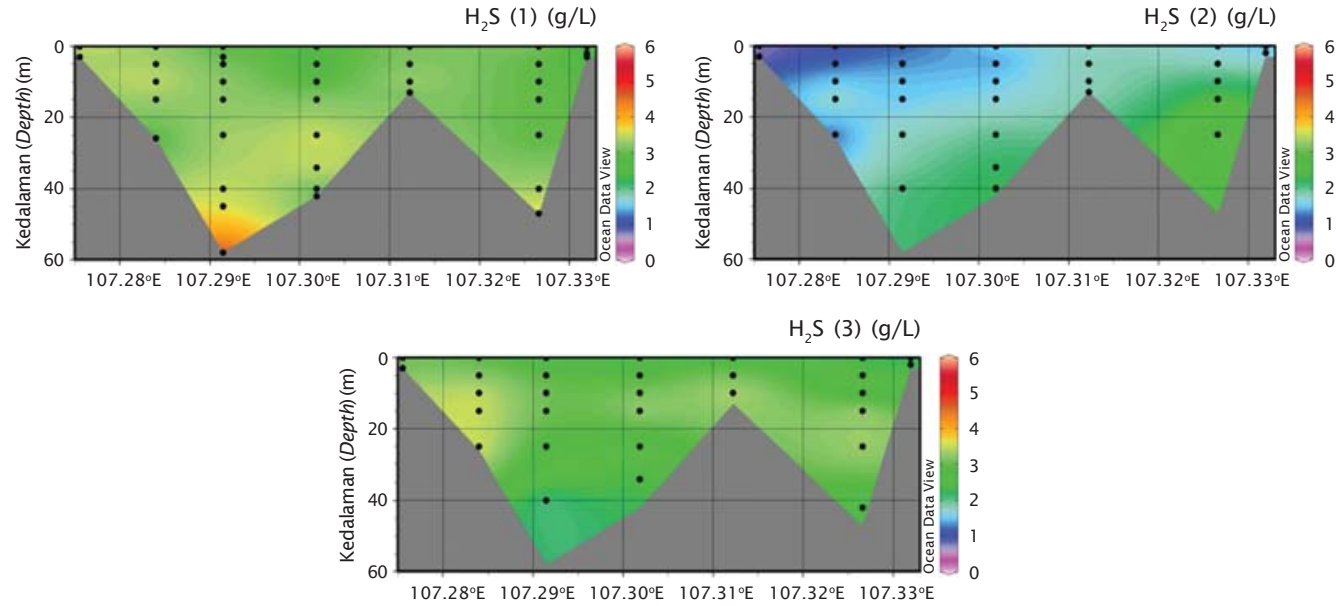

Gambar 10. Profil $\mathrm{H}_{2} \mathrm{~S}$ perairan secara membujur (stasiun 1, 2, 3, 4, 5, 6, dan 9) untuk waktu pengamatan yang berbeda: (1) 2 Mei, (2) 10 Juni, dan (3) 29 Juli 2011

Figure 10. $\mathrm{H}_{2} \mathrm{~S}$ profile along the longitude (station 1, 2, 3, 4, 5, 6, and 9) for different time observation: (1) 2 May, (2) 10 June, and (3) 29 July 2011

(Peraturan Pemerintah RI Nomor 82 Tahun 2001). Salah satu sumber tingginya kandungan $\mathrm{H}_{2} \mathrm{~S}$ disebabkan adanya proses dekomposisi limbah di dasar perairan.

\section{Kondisi Klimatologi}

Parameter klimatologi yang dikumpulkan dari tahun 2008-2011 meliputi: curah hujan, kecepatan angin, kelembaban relatif, dan suhu udara (Gambar 12). Pada tahun 2010 curah hujan sangat tinggi dibandingkan tahun 2008 , 2009, dan 2011, hal ini sangat relevan dengan debit air yang masuk pada tahun 2010 sangat tinggi (Gambar 2 dan 3). Namun pada tahun 2011 curah hujannya sangat turun drastis yaitu di bawah $5 \mathrm{~mm}$ /tahun. Kondisi ini menunjukkan adanya indikasi anomali iklim yang relatif susah diprediksi. 
$\mathrm{H}_{2} \mathrm{~S}(1)(\mathrm{g} / \mathrm{L})$
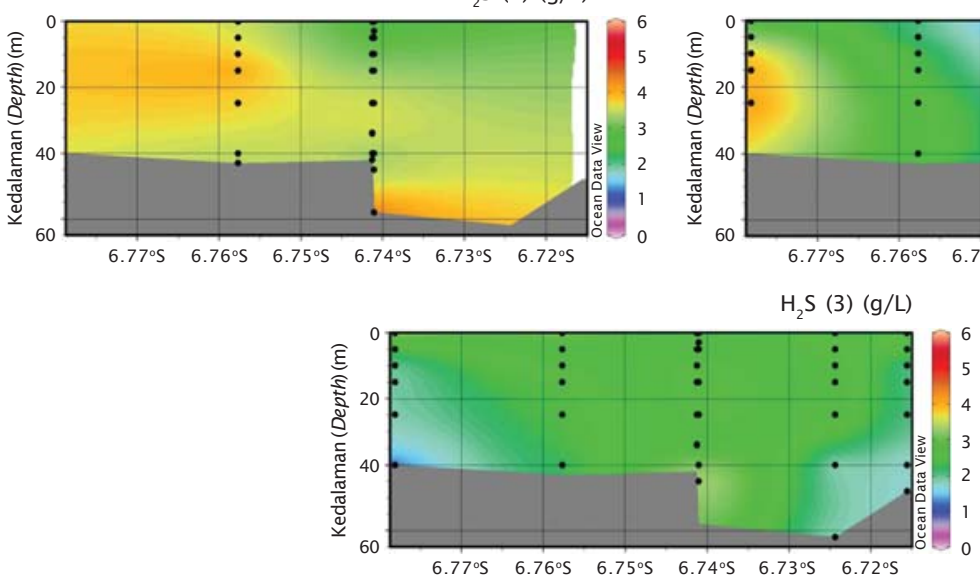

$\mathrm{H}_{2} \mathrm{~S}(2)(\mathrm{g} / \mathrm{L})$

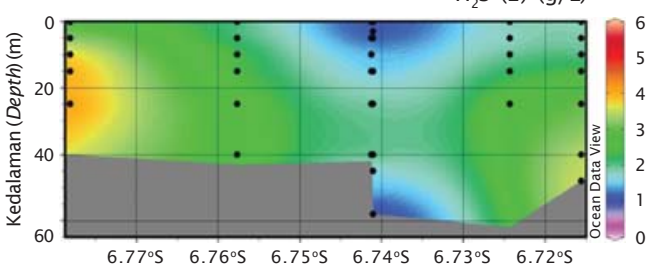

Gambar 11. Profil $\mathrm{H}_{2} \mathrm{~S}$ perairan secara melintang (stasiun 15, 10, 3, 4, 13, dan 12) untuk waktu pengamatan yang berbeda: (1) 2 Mei, (2) 10 Juni, dan (3) 29 Juli 2011

Figure 11. $H_{2}$ S profile along the latitude (station 15, 10, 3, 4, 13, and 12) for different time observation: (1) 2 May, (2) 10 June, and (3) 29 July 2011

Untuk parameter kecepatan angin menunjukkan hal yang sangat ekstrim pada tahun 2011 di mana kecepatan angin mencapai 12 $\mathrm{km} / \mathrm{jam}$. Apabila dibandingkan dengan tahun 2008, 2009, dan 2010 jauh di atas rata-rata. Kondisi ini dapat mengakibatkan rendahnya curah hujan pada tahun tersebut. Untuk kelembaban udara juga naik mencapai $100 \%$ pada tahun 2011 . Hal ini diduga ada hubungannya dengan curah hujan yang cukup rendah dan kecepatan angin yang cukup kencang, sehingga kelembaban udara menjadi naik.

Suhu udara yang merupakan parameter utama dalam pemanasan global dari tahun 2008-2011 grafiknya terus meningkat. Namun pada tahun 2011 tepatnya bulan Agustus terjadi penurunan suhu, namun demikian penurunan suhu tersebut masih di atas suhu ratarata dari tahun sebelumnya. Sehingga dari semua parameter klimatologi yang dianalisis memberikan gambaran adanya perubahan secara global dan secara umum sudah memberikan indikasi adanya pengaruh terhadap tingkat produktivitas kegiatan perikanan budidaya di Waduk Cirata. Hal ini didukung oleh pendapat Walther et al. (2002), Beukema \& Dekker (2005), Harley et al. (2006) perubahan parameter klimatologi kemungkinan akan berpengaruh pada waktu dan tingkat produktivitas dari lingkungan pesisir dan lautan. Intergovernmental Panel on Climate Change (IPCC) telah memprediksi terjadinya perubahan suhu udara sampai pada akhir abad 21 (2090-2099), perubahan yang terjadi berkisar antara $1,8^{\circ} \mathrm{C}$ (estimasi untuk prediksi terendah-B1) sampai $4^{\circ} \mathrm{C}$ (estimasi untuk prediksi tertinggi-A1 FI) (IPCC, 2007).

\section{Dampak Perubahan Iklim terhadap Produktivitas Keramba Jaring Apung}

Produksi ikan dari kegiatan budidaya di keramba jaring apung (KJA) dari tahun 20042010 menunjukkan tren yang menurun (Tabel 1). Hal ini disebabkan oleh beberapa faktor di antaranya daya dukung yang telah melebihi batas yang direkomendasikan, kondisi mutu lingkungan perairan yang sudah menurun, dan kemungkinan dampak anomali iklim (perubahan iklim). Dari pengamatan dan analisis terhadap data produktivitas pada tahun 20042007 yang dicirikan antara perbandingan luas KJA yang digunakan dengan produksi yang dihasilkan berbanding lurus, hal ini disebabkan salah satunya kondisi perairan Waduk Cirata masih mampu menopang kegiatan budidaya ikan dengan baik. Tetapi pada tahun 2008 dan 2009 sudah mengalami perubahan grafik produktivitas. Hal ini terlihat dari perbandingan antara luas lahan KJA yang digunakan dengan produksi yang dihasilkan berbanding terbalik. Nilai perbandingan antara luas lahan dengan produksi yang dihasilkan berturutturut dari tahun 2007-2009 sebesar 534,80 ha/ton; 526,00 ha/ton; dan 155,36 ha/ton. 


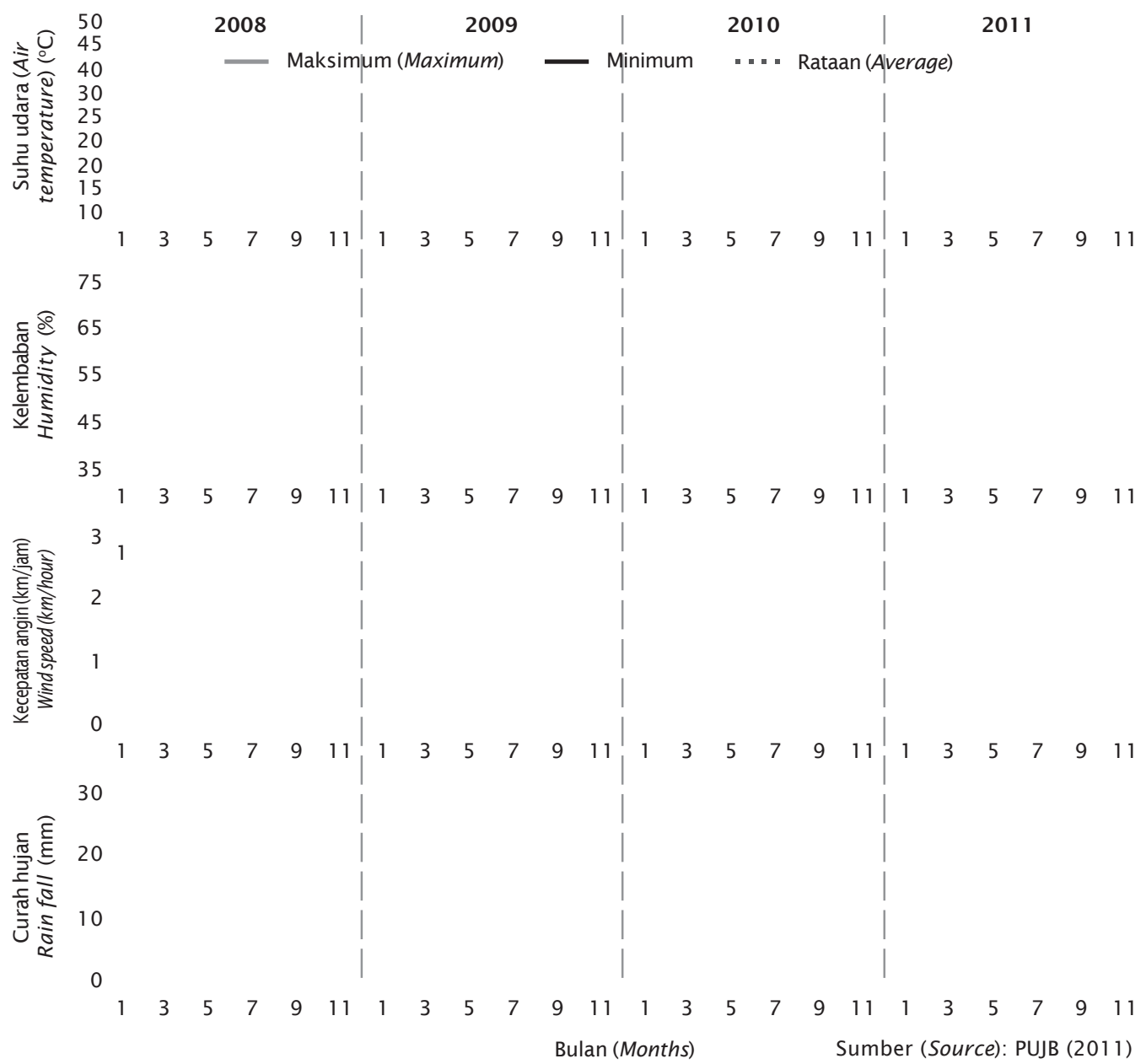

Gambar 12. Kondisi klimatologi dari tahun 2008-2011 di kawasan Waduk Cirata, Jawa Barat

Figure 12. Climatology condition from 2008-2011 in Cirata Reservoir, West Java

Namun tingkat produktivitas pada tahun 2010 menunjukkan angka yang berbeda yaitu sebesar 1.090,91 ha/ton dengan jumlah KJA mengalami penurunan sebesar $80,21 \%$ dari tahun 2009. Hal ini diduga efisiensi biaya produksi dengan setiap KJA mengoptimalkan penggunaan jaring kolor.

Jika dilihat dari anomali air sangat berpengaruh terhadap tingkat produktivitas perikanan dari Waduk Cirata. Salah satunya dari debit air pada tahun 2010 sangat tinggi (Gambar 2 dan 3), kondisi ini berbeda dengan tahun sebelumnya (tahun 2008 dan 2009). Untuk parameter kecepatan angin pada tahun 2010 menunjukkan angka di bawah 12 km/ jam yang terjadi pada tahun 2011 , tetapi masih sedikit di atas kecepatan angin rata-rata pada tahun 2008 dan 2009. Kondisi ini dapat mengakibatkan tingginya curah hujan pada tahun tersebut. Suhu udara yang merupakan parameter utama dalam pemanasan global dari tahun 2008-2011 grafiknya terus meningkat. Kondisi ini sangat mempengaruhi pada penurunan produksi dan produktivitas budidaya ikan di Waduk Cirata.

\section{KESIMPULAN}

Hasil penelitian menunjukkan suhu udara dari tahun 2008-2011 terus meningkat dan ini merupakan salah satu indikator utama terjadinya pemanasan global. Untuk parameter klimatologi lainnya: curah hujan, kelembaban, 


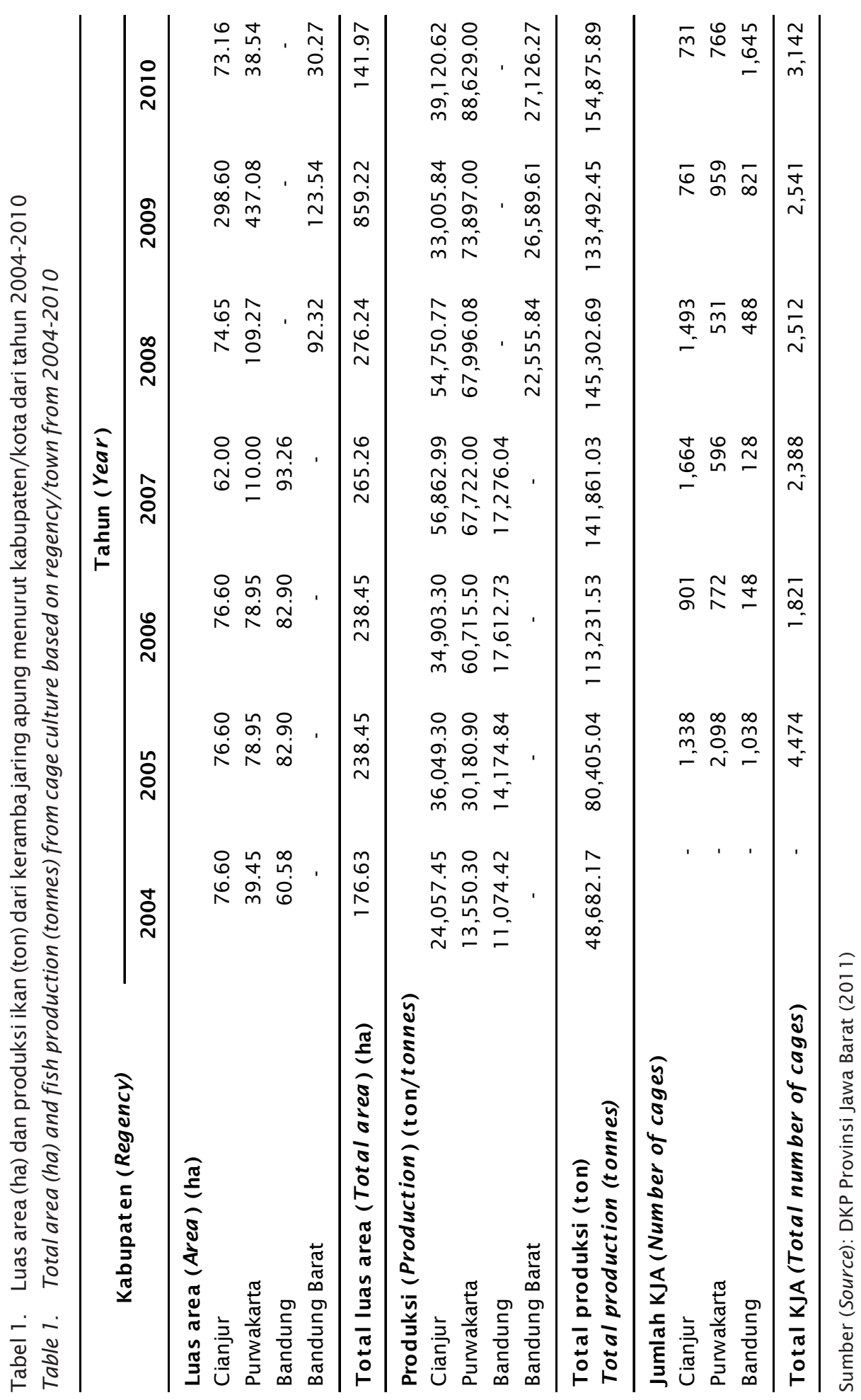


dan kecepatan angin sudah tidak teratur pada setiap tahunnya, data dari tahun ke tahun menunjukkan terjadi pergeseran yang relatif susah diprediksi. Parameter lingkungan perairan sudah mengalami penurunan di antaranya suhu air, $\mathrm{pH}$, dan oksigen terlarut yang berpengaruh terhadap sintasan ikan yang dipelihara walaupun masih dalam kondisi yang bisa digunakan untuk budidaya ikan (kritis). Dilihat dari produktivitas produksi ikan dari kegiatan budidaya ikan di keramba jaring apung dari tahun 2004-2010 terus menurun, padahal jumlah keramba jaring apung di Waduk Cirata terus meningkat. Dari perubahan parameter klimatologi maupun parameter perairan sudah ada indikasi pengaruh dari pemanasan global terhadap penurunan produktivitas budidaya ikan di Waduk Cirata.

\section{UCAPAN TERIMA KASIH}

Penulis mengucapkan terima kasih kepada tim survai lingkungan dan pemanasan global Balai Penelitian dan Pengembangan Budidaya Air Tawar, Bogor yang telah membantu kelancaran pengumpulan data lapangan. Penelitian ini merupakan bagian dari penelitian kajian dampak pemanasan global terhadap perikanan budidaya di Waduk Cirata Balai Penelitian dan Pengembangan Budidaya Air Tawar Tahun Anggaran 2011.

\section{DAFTAR ACUAN}

Badan Pengelola Waduk Cirata (BPWC). 2009. Presentasi BPWC: dalam sosialisasi Co Manajemen Perikanan Waduk Cirata untuk Stakeholder, DKP, 14-1 7 April 2009.

Badan Pengelola Waduk Cirata (BPWC). 2011. Laporan Pemantauan Kualitas Air Waduk Cirata Triwulan II. Bandung: BPWC, $40 \mathrm{hlm}$.

Bardach, J.E. 1989. Global warming and the coastal zone. Climatic Change, 15: 117150.

Beukema, J.J. \& Dekker, R. 2005. Decline of recruitment success in cockles and other bivalve in the Wadden Sea: possible role of climate change, predation on postlarvae and fisheries. Marine Ecology Progress Series, 287: 149-167.

Boyd, C.E. \& Lichtkoppler. 1982. Water quality management in pond fish culture. Auburn University. Auburn Alabama, 30 pp.

Cholik, F., Wijono, A., \& Arifudin. 1986. Pengelolaan kualitas air kolam. Direktorat Jenderal Perikanan. Jakarta, $52 \mathrm{hlm}$.
Cochrane, K., De Young, C., Soto, D., \& Bahri, T. 2009. Climate change implication for fisheries and aquaculture: overview of current scientific knowledge (Eds.). FAO Fisheries and Aquaculture Technical Paper. No. 530. Rome, $212 \mathrm{pp}$.

Effendi, H. 2003. Telaah kualitas air bagi pengelolaan sumberdaya dan lingkungan. Kanisius. Jakarta, $258 \mathrm{hlm}$.

Gunarso, W. 1985. Tingkah laku ikan dalam hubungannya dengan alat tangkap, metode dan teknik penangkapan. Diktat Kuliah (tidak dipublikasikan). Jurusan Pemanfaatan Sumberdaya Perikanan. Fakultas Perikanan dan Ilmu Kelautan. Institut Pertanian Bogor. Bogor, $149 \mathrm{hlm}$.

Handisyde, N.T., Ross, L.G., Badjeck, M-C., \& Allison, E.H. 2006. The effects of climate change on world aquaculture: a global perspective. Available online at www. aquacultur.stir.ac.uk/GISAP/gis-group/ climate.php, $151 \mathrm{pp}$.

Harley, C.D.G., Hughes, A.R., Hultgren, K.M., Miner, B.G., Sorte, C.J.B., Thornber, C.S., Rodriguez, L.F., Tomanek, L., \& Williams, A.L. 2006. The impact of climate change in coastal marine systems. Ecology Letters, 9: 228-241.

Husen, M. 2004. Upaya perbaikan lingkungan untuk menunjang kesinambungan budi daya ikan dalam keramba jaring apung (KJA). Pengembangan Budi Daya Perikanan di Perairan Waduk. Suatu Upaya Pemecahan Masalah Budi Daya Ikan dalam Keramba Jaring Apung (KJA). Pusat Riset Perikanan Budidaya. Jakarta, hlm. 9-11.

IPCC. 2007. Summary for policymakers. In: Climate change 2007: the physical science basis. Contribution of working group I to the fourth assessment report of the intergovernmental panel of climate change (Solomon, S., Qin, D., Manning, M., Chen, Z., Marquis, M., Averyt, K.B., Tignor, M., \& Miller, H.L. (Eds.). Cambridge University Press, Cambridge, United Kingkom and New York, NY, USA, 187 pp.

Mackereth, F.J.H., Heron, J., \& Talling, J.F. 1989. Water Analysis. Fresh-Water Biological Association, Cumbira, UK. 120.

Meisner, J.D. \& Shuter, B.J. 1992. Assessing potential effect of global climate change on tropical freshwater fishes. GeoJournal, 28(1): 21-27.

Nontji, A. 1993. Laut Nusantara (Marine Nusantara). Djambatan Jakarta. Jakarta, 365 hlm. 
Peraturan Pemerintah RI Nomor 82 Tahun 2001. Tentang Pengelolaan Kualitas Air dan Pengendalian Pencemaran Air. Jakarta, 46 hlm.

Prihadi, T.H. 2005. Pengelolaan budidaya ikan secara lestari di Waduk (Studi kasus di perairan Waduk Cirata, Jawa Barat). Disertasi. Pasca Sarjana Institut Pertanian Bogor (tidak dipublikasikan). Bogor, 271 hlm.

PT Pembangkitan Jawa Bali, Unit Pembangkitan Cirata. 2011 . Data Klimatologi, Rekapitulasi Klimatologi. Sistem Manajemen Perusahaan ISO 9001, ISO 14001 SMK3, $48 \mathrm{hlm}$.

Radiarta, I N., Kristanto, A.H., \& Saputra, A. 2011. Kondisi meteorologi, klimatologi, dan perikanan di kawasan Waduk Cirata, Jawa Barat: analisis awal kemungkinan dampak pemanasan global terhadap perikanan budidaya. J. Ris. Akuakultur, 6(2): 495-506.

Radiarta, I N., Prihadi, T.H., \& Sunarno, M.T. 2005. Pemantauan perikanan budidaya berbasis keramba jaring apung di Waduk Cirata dengan menggunakan multi-temporal data Landsat 7. Pusat Riset Perikanan Jakarta. Warta Penelitian Perikanan Indonesia, hlm. 1-8.

Rusbiantoro, D. 2008. Global Warming for Beginner. Pengantar Komprehensif Tentang Pemanasan Global. Penembahan. Yogyakarta, $112 \mathrm{hlm}$.

Saputra, A., Radiarta, I N., Prihadi, T.H., Priono, B., \& Kusrini, E. 2007. Kajian kualitas air di Teluk Kapontori untuk mendukung perikanan budidaya yang berkelanjutan dan ramah lingkungan. Pengembangan Teknologi Perikanan Budidaya. Balai Besar Budidaya Perikanan Laut. Bati, hlm. 191-199

Schlitzer, R. 2011 . Ocean Data View. WWW page. http://odv.awi.de.
Stickney. 2000. Culture of Nonsalmonid Freshwater Fishes. $2^{\text {nd }}$ (eds). CRC. Press. Boca Raton, Ann Arbor, London, Tokyo.

Sunarti. 1992. Pengukuran parameter kualitas air pads longyam dengan tingkat kepadatan 10.000 ikan nila dan 3.000 ikan mas. Laporan Praktek lapangan di Balai Budidaya Air Tawar Sukabumi, $97 \mathrm{hlm}$.

Sudradjat. A. 2006. Glosarium Kelautan dan Perikanan. Pusat Riset Perikanan Budidaya. Badan Riset Kelautan dan Perikanan. Departemen Kelautan dan Perikanan. Jakarta, $192 \mathrm{hlm}$.

Sverdrup, H., Johson, G., \& Fleming, R.H. 1961. The oceans, their physics, chemistry and general biology. Prentice-Hall, Inc. Englowed, 1,087 pp.

Tarsim. 2000. Studi Kualitas Air dan Produksi Tambak Udang Intensif di PT. Moisson Makmur, Tangerang, Jawa Barat. Skripsi. Jurusan Budidaya Perairan, Fakultas Perikanan dan Ilmu Kelautan, Institut Pertanian Bogor.

Walther, G-R., Post, E., Convey, P., Menzel, A., Parmesan, C., Beebee, T.J.C., Fromentin, JM., Hoegh-Guldberg, O., \& Barlein, F. 2002. Ecological responses to recent climate change. Nature, 416: 389-395.

Widiyati, A., Djokosetiyanto, D., Begen, D.G., Kholil, A., \& Abidin, Z. 2011 . Model dinamik pengelolaan limbah di lingkungan perairan keramba jaring apung Waduk Cirata Jawa Barat). Analisis Kebijakan Pembangunan Perikanan Budidaya 2011 . Swakarya, hlm. 181-197.

Widiyati, A. \& Begen, D.G. 2012. Kajian aspek keberlanjutan pada pengelolaan perikanan budidaya keramba jaring apung di Waduk Cirata (Jawa Barat). J. Ris. Akuakultur, 7(1): 121-129. 